\title{
The Consciousness of History in Malaysia: The Ideas on Merdeka Day in Sarawak
}

\author{
Muhaimin Sulam ${ }^{1 *}$, Norena Abd Karim Zamri², Ahmad Murad Merican ${ }^{3}$ \\ ${ }^{1}$ Department of Management and Humanities, Universiti Teknologi PETRONAS, 32610, Bandar Seri Iskandar, \\ Malaysia \\ ${ }^{2}$ Department of Management and Humanities, Universiti Teknologi PETRONAS, 32610, Bandar Seri Iskandar, \\ Malaysia \\ ${ }^{3}$ Centre of Policy Research and International Studies, Universiti Sains Malaysia, 11800, Pulau Pinang, Malaysia
}

\begin{abstract}
For decades, the Malaysian national history is in a stable condition and not being challenged by anyone. The enhancement of national history is constantly progress through educational system starting from primary school to university level. The consciousness of national history is the foundation for the unity of the people and country development. Though, from time to time, the status quo starts to face the challenges and disputes which began with small scale and got bigger. This could trigger a national issue. Thus, this study focus on the date of Independence Day amongst Sarawak citizens. As one of the states that form the Federation of Malaysia in 1963, the history of Sarawak as a separate nation with the history of Malaysia has been detected. The consciousness of Merdeka Day for Sarawakian is more to refer to the establishment of the federation rather than the date of August 31, 1957 as the day of independent. To add, this research is to identify the level of consciousness in revising the national history amongst Sarawakian. This study also delves the understanding of "Merdeka" from Sarawakians' point of view and discuss whether the nation history is proportionate for the Sarawakian. For the methodology, this study applies quantitative and qualitative approaches, a concurrent triangulation mixed method design. The phases of data collection are two including surveys and focus group discussions. Generally, the result shows that the Sarawakian have a new consciousness of the national history.
\end{abstract}

Type of Paper: Empirical

Keywords: Consciousness; National History; Merdeka; Sarawak; Malaysia

\section{Introduction}

The idea of Malaysian history is now facing a new volume of consciousness, giving a huge challenge to the interpretation of history especially in the school textbook. As being claimed by Hein \& Selden (2000), "history and civics textbooks in most societies present an 'official' story, highlighting narratives that shape contemporary patriotism". The contestation over textbooks contents is due to the system of education, which is authoritative by the nation, delimit proper behavior of citizens, and sketch the imagine nation. "The nature of the textbook is carried directly or indirectly, they carry the imprimatur of the state, and they have enormous authority" (Hein \& Selden, 2000).

National history through educational system has been questioned. Thus, this paper will focus on the event of independence to view the consciousness of Sarawakian, which covered the study area. National independence can be described as one of the vital event in a country's formation. The development of a new media helps to promote different ideas and interpretation about events that significance for the country, as such Independence Day or 'Hari Merdeka' has become one of the contestation.

\footnotetext{
* Corresponding author: muhaiminsulam@utp.edu.my
} 
The root word of 'independence' is independent. Independent means free from colonialism, confinement, protectorate, not relying on others, stand alone and sovereign (Dewan, 2002). Commemorate the independence of a country or nation that is free from any form of colonialism described as a country's greatness day. Independent also is one of the liberty to develop a country or nation according to own rules without the intervention of others.

Independence Day is a day to commemorate the birth of a country. Independence is a climax of a crusade of the locals and a symbol of nation country's sovereign. To add, independence is a yield of struggle and unity of citizens which requires high sacrifices including a soul. Independence Day is the past, however in Malaysia, since it was celebrated on 31 August 1957 each year, the date and day of independence was not being questioned until there is a wakeup call by some the Sarawak community. Today, the factual errors and misleading assumptions occurred among Sarawak community especially the on the topic of Independence Day.

For the majority of Sarawakian, the Independence Day is no longer to be reconciled on 31 August 1957 but believed it should be on 22 July 1963. This date reconciles the date when Governor Colonial Sir Alexander Waddell appointed Stephen Kalong Ningkan to be the first Sarawak Chief Minister and the formation of High Council Members as the first Sarawak's cabinet (Sarawak, 2016). To the Sarawakian, the event is the declaration that Sarawak is free from British by forming a sovereign state.

\section{The Idea of 'Merdeka'}

Starting from the year of 2010, government declared $16^{\text {th }}$ September as Malaysia Day (Hari Malaysia) as to commemorate the establishment of the Malaysian Federation on the same date in 1963 (Razak, 2011). It marked the joining together of Malaya, Singapore, Sarawak and North Borneo (Sabah) (Stockwell, 2008). The formation of the new federation was planned to occur on 1st of June 1963, but was later postponed to 31st of August 1963, in order to coincide with the sixth Malayan Independence Day. However, due to several issues related to the Indonesian and the Filipino objection to the formation of Malaysia delayed the declaration to September 16 of the same year. The postponement was also done to give the United Nations' team sufficient time to conduct referendums in North Borneo (now Sabah) and Sarawak regarding the two states participation in the new federation (Stockwell, 2008).

Generally, in August and September, Malaysia will celebrate its national day on two dates, the Independence Day (Hari Kemerdekaan) and Malaysia Day (Hari Malaysia). Both of these date play a significant role in the heart of Malaysian. However, the idea having Independence Day celebration and Malaysia Day was not meaningful for Sarawakian compared to celebrating $22^{\text {nd }} \mathrm{July}$. It was claimed to be Malaya-centric and caused heated debate among Sarawakian (Fernandez, 2013; Kaung, 2012).

It took 47 years since Malaysia was formed for us to start celebrating September 16 as Malaysia day and a public holiday beginning 2010. Thus, it also took 50 years since Malaysia's birth for Sarawak to start celebrating its own independence anniversary on July 22 beginning 2013. Apart from that, the idea of "Sarawak Merdeka" is more dominant in social media especially amongst youngsters. Historically, Sarawak gained its independence on July,22 in 1963.

Through "google search", the earliest blog sparked the questions about Sarawak Independent on 22 July 1963 is Radin's Blog Discussion from his writes posted on 21 July 2012 entitled "22 Julai: Hari Kemerdekaan Sarawak" (Radin, 2012). The climax debate on this issue and the effect with Malaysia's Independence Day on 31 August 1963 is when Sarawak Chief Minister, Adenan Satim announced 22 July is a Sarawak Day throughout his pre-election tour "Sejiwa Sanada" in Kuching on 23 April 2016. (Yu Ji, 2016). This is the official statement from the highest rank leader Sarawak state. This statement is the climate amongst the public debate since 2012. Later, the statement is supported with the events organized by Sarawak government such as "Upacara Memperingati Hari Sarawak Merdeka Daripada Penjajah" on 22 Julai 2013 by Yang di-Pertua Negeri Sarawak, Tun Datuk Patinggi Abang Muhamad Salahuddin along Sarawak's Riverbank.

Before that, during press conference on 20 July 2013 in "Wisma Bapa Kemerdekaan", Kuching, Sarawak's Minister of Resource Planning and Environment II, Datuk Amar Awang Tengah Ali Hasan stated that their side are thrive to include Sarawak Independent event in Malaysian education syllabus. To add, Datuk Seri Tiong King Sing, Bintulu's member of parliament, is one of the politician who fighting for the event to be included into the national education syllabus (Awani, 2015). 
In fact, there is one article wrote by Mohamad Razif bin Awang Yusuf (UKOM Sarawak) entitled "22 Julai Hari Sarawak Merdeka Daripada Penjajah: 50 Tahun Sarawak Dahulu, Kini dan Akan Datang" published in website of Jabatan Hal Ehwal Khas (JASA), Malaysian Communications and Multimedia Ministry on $4^{\text {th }}$ July 2014. The article gives a view on the establishment of self-government headed by local citizens. There is one statement in that article claimed that Sarawak Independence Day is to be on 22 July 1993. Thus this created different views from the main version of a nation's history. Ironically, this controversial statement also comes from the ministry.

The opposition also support the statement from Sarawak government. One of the 'Gerakan Pemisah' so called "Sabah Sarawak Keluar Malaysia - Sabah Sarawak Merdeka" used online internet as a platform to spread their influence in order to support the effort making the date as Sarawak Independence Day (William, 2015). Other than that, Jofri Jaraiee from PAS Sarawak, demand the state government to announce the date as a Sarawak Day (Jaraiee, 2013)

\section{Research Method}

This study employed a quantitative and qualitative approach as the methodology, a concurrent, triangulation mixed method design. This study utilized a mixed methods study design, which Cresswell and Plano Clark (Cresswell \& Plano Clark, 2007) describe as a type of research in which qualitative and quantitative data are collected, analyzed and integrated to better understand a research problem. By using these methods, it allows researchers to employ a variety of strategies to answer questions that cannot be addressed by qualitative or quantitative methods exclusively. Specifically, this research employed an exploratory sequential design. In employing a transformative exploratory sequential instrument design, this study began with the collection of quantitative data which then guided the development of a qualitative instrument- focus group discussion.

\subsection{Phase 1: Surveys}

In this study, the Sarawak citizens view from these four sections have been collected. Under school section, the set of questionnaires have been distributed to five national schools with each of the school comprises of one History teacher and two form 4 students. In addition, the other eight and seven set of questionnaires have been distributed to two national Chinese schools with each of the school consists of two history teacher and the balance is the form 4 students. The balance of 10 questionnaires have been distributed to Independent Chinese School. For the others sections, the criteria as stated below. From the 61 questionnaires distributed, the collaborator managed to return 314 answered questionnaires, and the total of 314 questionnaires have been used for this study. The other 6 questionnaires have not been returned. Collected data were exported to Statistical Package of the Social Sciences (SPSS) for analyses. Data were analyzed and descriptive statistics were used to describe findings.

Table 1. Division for the survey distribution

\begin{tabular}{|c|c|c|}
\hline Section & Criteria & Number \\
\hline \multirow[t]{3}{*}{ School } & National School & 40 \\
\hline & National Chinese School & \\
\hline & Independent Chinese School & \\
\hline University & Academic and Non- Academic Staff & 40 \\
\hline Public Sector & According to Ethnicity & 40 \\
\hline \multirow[t]{2}{*}{ NGO } & According to Ethnicity & 40 \\
\hline & TOTAL & 320 \\
\hline
\end{tabular}

\subsection{Phase 2: Focus group}

Two focus groups with 25 participants were conducted at Miri and Kuching, Sarawak. The participants in focus group discussions were selected along the basis of purposiveness in a given subject rather than representativeness. This is because; they are able to provide relevant information on the topic was given and provide insights that are personally important to them. Research collaborator was appointed in selecting and recruiting the focus group participants. The participants were chosen on the basis of socio-demographic variations, in terms of age, gender, ethnicity and 
profession. This was desirable to reflect a wide scope of experience. An email outlining the objectives of the research was sent out to the participants before the discussion.

During the discussion, participants were informed about anonymity and confidentiality. Written informed consents were obtained from all participants. The focus group questions were developed based on a review of the literature on historical consciousness; studies related to history trajectories and the constitution were designed to look how communities in Sarawak viewed national narrative (mainstream history), promptly how they see themselves as part of it. The questions and statements were used to guide the discussion, but probes were also used to further explore certain comments or ideas. The data were audio-recorded with the permission. Each group discussion lasted approximately two hours.

\section{Findings}

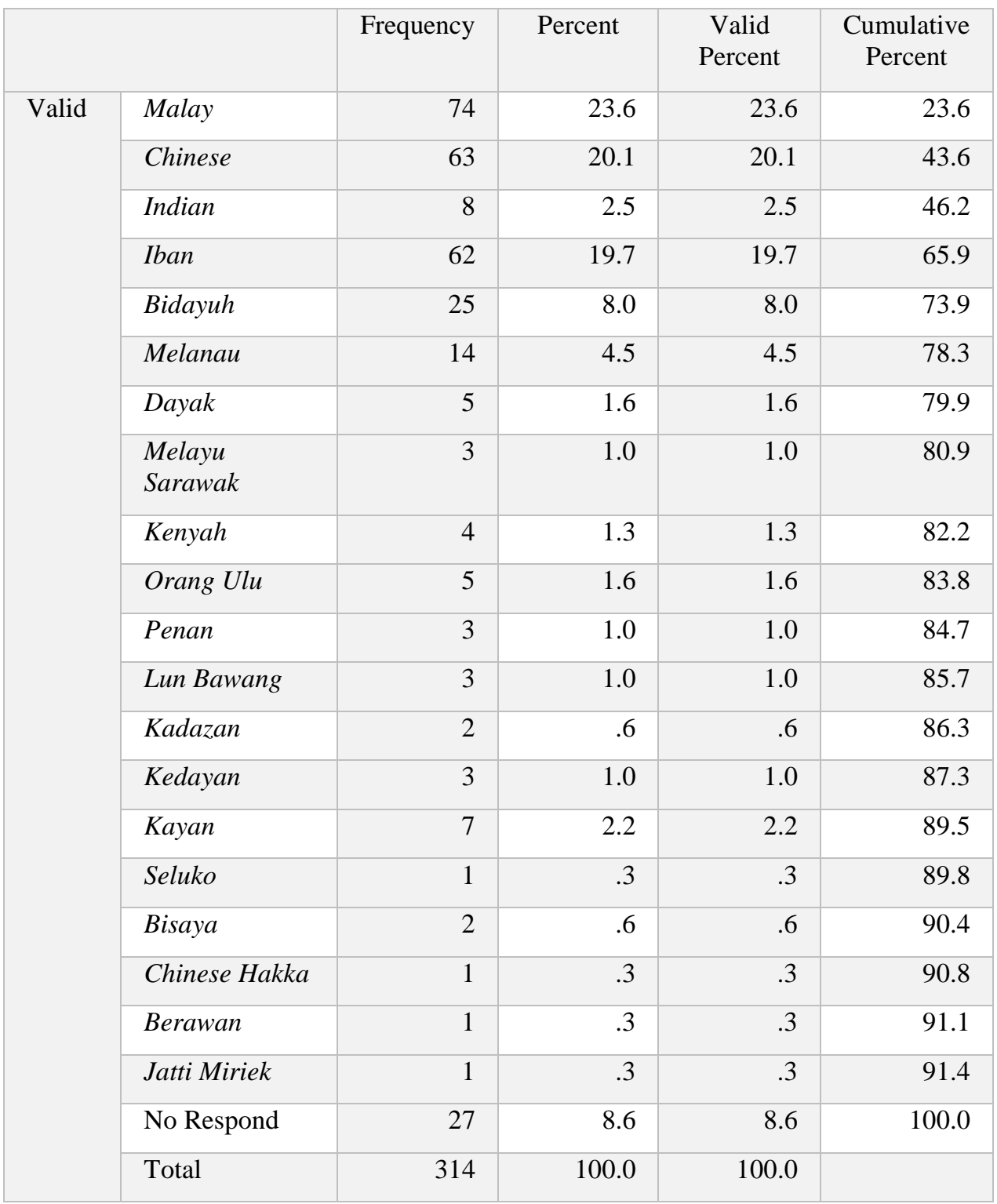

Table 2. Ethnicity 


\subsection{Phase 1: Surveys}

\subsubsection{Ethnicity}

The results of the type of ethnicity of the respondents in Sarawak is presented in the Table 2. The total respondents are 314 and from the data obtain, the number of ethnicity involved in this study are 20. From the survey collected, most of the data are gathered from Malay ethnic which make up of $23.6 \%$ of total respondents ( 74 respondents). Then, follow by Chinese that with $20.1 \%$ from the total respondents (63 respondents), Iban that with $19.7 \%$ from the total respondents (62 respondents) and Bidayuh that with $8.0 \%$ from the total respondents (25 respondents). To add, 14 (4.5\%) respondents are from Melanau ethnic group, 8 respondents (2.5\%) are from India ethnic group, 7 respondents (2.2\%) are from Kayan ethnic group, 5 respondents (1.6\%) are from Dayak and Orang Ulu ethnic group, 4 respondents (1.3\%) are from Kenyah ethnic group, 3 respondents (1.0\%) are from Kedayan and Lun Bawang and Penan ethnic group and 2 respondents $(0.6 \%)$ are from Kadazan and Bisaya ethnic group. Also, Seluko, Chinese Hakka, Berawan and Jatti Miriek share the same number of respondents which are 1 respondent $(0.3 \%)$. The other $8.6 \%$ of the respondents (27 respondents) are not respond to this question.

In response to ethnicity and online media usage, the descriptive results reveal that majority of the respondents participated in this study use online media between 1 to 2 hours which left 53 out of 314 or about $16.9 \%$ use online media in less than 1 hour. The study also found out that $53.2 \%$ of the respondents' views are being influenced by online media, while $12.1 \%$ of the respondents do not being influenced by the online media.

\subsubsection{Level of Consciousness}

Respondents were then asked to rate their agreement and responses were then tabulated according to the ethnicity (refer Figure 1.0). From the survey, it records majority of the respondents agree that Malaysian history needs to be revised by counting the "strongly agree" and "agree" and giving a result $66.24 \%$ (208 respondents). This make up of Malay, Chinese, Indian, Iban, Bidayuh, Melanau, Dayak, Melayu Sarawak, Kenyah, Orang Ulu, Lun Bawang, Kadazan, Kedayan, Kayan, Seluko, Bisaya, Chinese Hakka, Berawan, Jatti Miriek and 'No Respond'. Then, there is $26.75 \%$ (84 respondents) at the state neither agree nor disagree about this matter. From the table also, it shows $7.01 \%$ (22 respondents) representing Malay, Chinese, Iban, Bidayuh, Penan, Kedayan, Kayan and 'No Respond' disagree that the History of Malaysia should be revised. This is by counting the "disagree" and "strongly disagree" as indicated below.

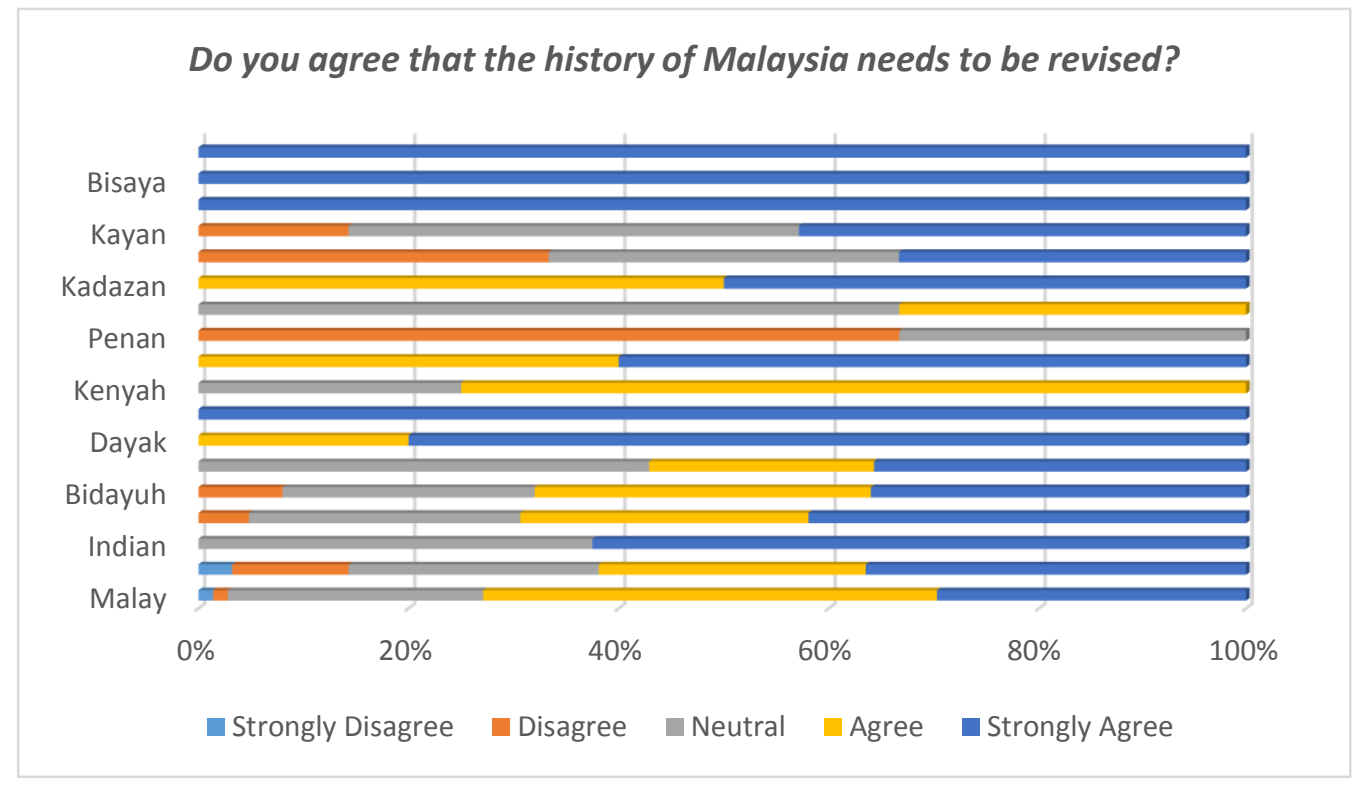

Figure 1. Level of consciousness according to ethnicity 
In addition of historical consciousness, respondents were also asked to rate their agreements. From the table below, it shows that, the highest mean score will represent the most agree issue by respondents whereas the least mean score will represent the least agree issue by the respondents in term of consciousness about Malaysian history for the Sarawak citizens. From the survey and analysis, the most respondents agree is about the History of Malaysia need to be revised with the mean score of 3.952. Whereas the least agree issue is the issue of online sources where they agree with the online sources related to Sarawak perspectives of Malaysian history with a mean score of 3.086 (refer Figure 2.0). This highlights that most Sarawak respondents agree that the History of Malaysia needs to be revised thus new insights, fair and true Malaysian history can be generated especially from the Sarawak perspectives.

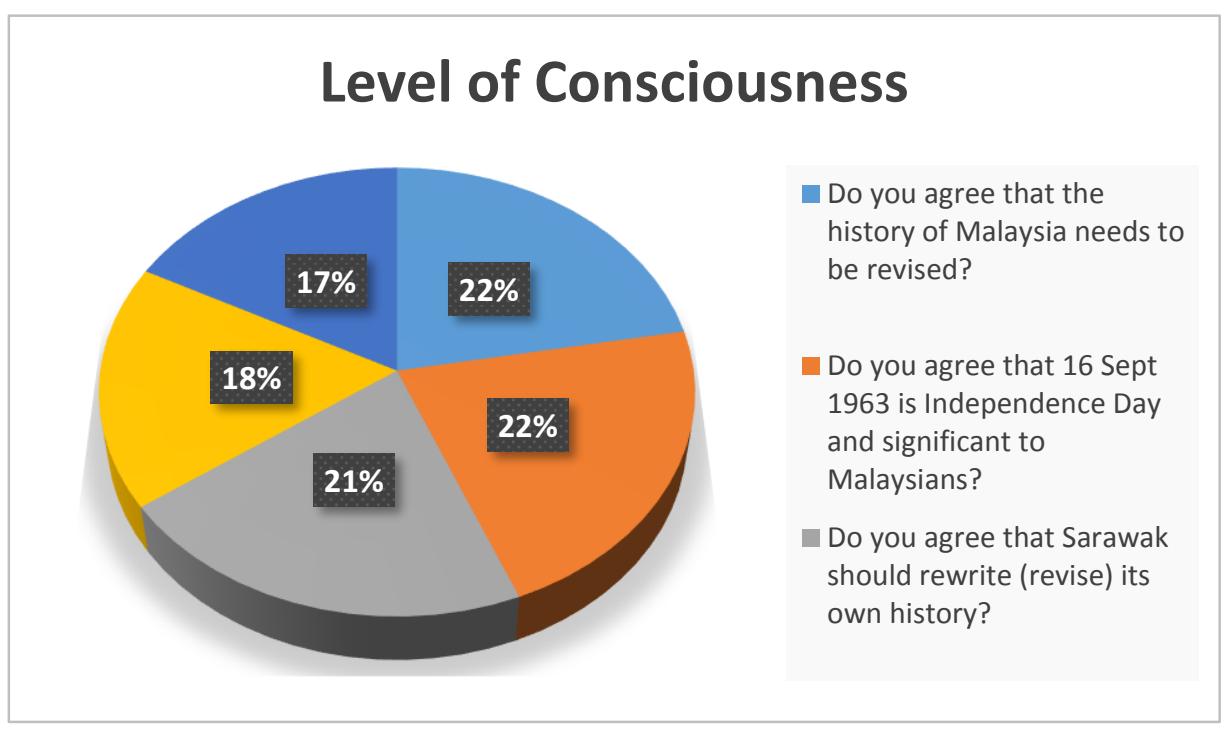

Figure 2. Level of consciousness

\subsection{Phase 2: Focus Group Discussion}

This study adopts focus group discussion to collect data in order to have an in-depth data as compared to survey. Two focus groups were conducted in Kuching and Miri and the participants came from different ethnic with a different education, gender, politic, age and career. There were 13 participants in Miri and 12 participants in Kuching. Each session was conducted within two hours and covered the topic that have been prepared by the team.

First, based on the transcript, there is a strong connection in both places between history consciousness and new media. Generally, the participants stated that national history have been controlled by elite group who have the power to write a text book that become the source of nation history. Majority of the participants have a view that national history is based on text book. Currently, the expansion of new media such blog, online news, WhatsApp and other social media have changed their views. The major topic highlighted throughout the discussion was mainly on Sarawak Independence Day.

For Sarawakian, the term 'Sarawak Merdeka' has significant impact to their lives. For them, Sarawak was granted self-government on July 22, 1963. It was the day that the flag of Sarawak hoisted. Thus, the joy of celebrating $31^{\text {st }}$ August as Independence Day does not significant to the heart of Sarawakian. The implication of the indictment of 'Sarawak Merdeka' and recognition Sarawak as 'Negara' (nation)-proclaimed by some of the Sarawakian, seems contradict with the act in Malaysia constitution amendment 1976. However, this interpretation is dominant amongst Sarawak government leader and public.

The major issues highlighted from the focus group discussion was most of them wanted the national history to be revised. They wanted the fact of 'Sarawak Merdeka' to be included into the syllabus. However, some of the participants whom worked as government servant represented themselves as neutral, although deep inside their heart they have their own stand on the issue. The reason behind of this attitude shown is because they refuse to involve in sensitive issues. 
Majority of the respondent showed negative responds as they could not accept $31^{\text {st }}$ August 1957 as Malaysia's Independence Day. For them, Sarawak is still colonized by the British in 1957 and only gained their self-governance in 1963. On the other hand, most of the participants agreed that their views were strongly being influenced by the new media. Through the new media, the new insight of the importance of 22 July, 1963 were elevated.

According to Prof Michael Leigh, Sarawak was granted to govern their own state since 22 July, 1963 and lasted until 16 September 1963. It is prior to the condition that it would join to form the Federation of Malaysia on 16 September the same year (Welman, 2011). Apparently, it is not an independence but more to a debut to a process of transition towards the independence.

\section{Conclusion}

Different version of history in one nation is not something new or as a hitch to be accepted by society. It has been accepted in European countries such United Kingdom, Sweden and Germany (Körber, 2015; Luisa, 2011). For them, it is a process of thinking skills, providing looking at certain phenomena from multi-angle or perspective.

The issues of national history have become political issue due to the nature of the history itself as political history and less focusing on the country's social and economic development (Ting, 2014). When the history is more prone to highlights political history, it will be influenced by the changes that happens in the country's political issue. Those who have interest will use the new media as a medium to spread their propaganda.

Contrastingly, the new media work as a tool to evaluate the history. Hence, the sense of history consciousness is increasing from time to time. One of the ways to surpass the dumping of history information in new media is to have an individual strainer who have a credibility and open mind towards new findings and views. This is also a contribution to the national development.

The current national history is incomplete and always in a process of amendments, improvements and reinterpretation from time to time. Thus public historian who has the integrity plays a crucial role in developing national history. Although from the reality, we are going to deal and jungle with different opinions and views but in the end, through the maturity process, the result will be benefited for the sake of the country.

The data collected in Kuching and Miri showed that the national history consciousness for the Sarawakian is 'multiple'. Affirmations from the people to revise and rewrite national history is an alarm on history consciousness. An effort to revise national history should be no issue as the process to reproduce new syllabus will include all parties. The process to revise textbook can be inclusive and fair to the Sarawakian who believes their history has been marginalized. An open and wide involvement is a condition towards the process to revise and rewrite national history.

However, the effort to include all historical events into the syllabus is a tough process due to the time and space limitation. One of the best way to overcome this issue is Malaysia historiography must have one character that can is significance by all parties and it is not a just a matter of propaganda. For instance, "I Malaysia" concept is a concept that is significance by all parties or only for part of government politics? Is our forefather- Tunku Abdul Rahman, former first Malaysia Prime Minister being owned by all races and parties?

As what have been explained before, this study discovered that a new consciousness towards Sarawak Independence date have been identified. From the gathered data, Sarawakian are mostly incline to celebrate Independence Day (Hari Kemerdekaan) 31 August, 1957. The new date, 22 July, 1963 as being claimed as Sarawak Independence Day is more to have a political value rather than history value. Generally, historian reject the event which they claimed as a symbol of Sarawak Independence Day. The event is during the inauguration of Chief Minister and formation of Sarawak cabinet to rule Sarawak. The event is actually a process towards independence.

The history on Malaysia's Independence Day (Hari Kemerdekaan) should remain on 31 August, 1957. The celebration to commemorate the inauguration of Chief Minister and formation of the first Sarawak cabinet can be claimed as a process for the Sarawak to get independence. This ritual has been practiced in United States which is in federal country that unites 50 states. United States have been declared as an independency country on 4 July 1776 through the merger of 13 states. Then, a few states joined the country on different dates. Apparently, all states in United State is maintained with 4 July 1776 as Independence Day (Hole, 2001).

National history consciousness will be expressive with the consciousness towards the nature of history and the history documentation to be more open and comprehensive. In the end, this consciousness will form more solid understanding 
in a multi ethnic society and separated geographically. The consciousness is the main priority for the society to move forward in the challenging future.

\section{Acknowledgements}

This research has been supported by research grant from the Malaysian Communications and Multimedia Commission Networked Media Research Collaborative Programme with Universiti Teknologi PETRONAS (Project Number: 0153AB-G16). The authors are also thankful to the members of this research grant for providing support and commitment.

\section{References}

Awani, A. (2015). Semak buku teks sejarah, masukkan Hari Kemerdekaan Sarawak. Retrieved October 9, 2016, from http://www.astroawani.com/berita-malaysia/semak-buku-teks-sejarah-masukkan-hari-kemerdekaan-sarawak66654

Dewan, K. (2002). Kamus Dewan. Kuala Lumpur: Dewan Bahasa dan Pustaka.

Fernandez, J. (2013). Sabah, Sarawak: 50 Years in Malaysia plagued by bad politics — Joe Fernadez. Malay Mail Online.

Hein, L., \& Selden, M. (2000). Censoring History: Perspectives on Nationalism and War in the Twentieth Century

Hole, R. (2001). The American Declaration of Independence of July 4th , 1776 Why Declare Independence ? Retrieved October 15, 2016, from http://www.historytoday.com/robert-hole/american-declaration-independence-july-4th1776

Jaraiee, J. (2013). Hari Kemerdekaan Sarawak wajar diwartakan. Sinar Online. Retrieved from http://www.sinarharian.com.my/karya/pendapat/hari-kemerdekaan-sarawak-wajar-diwartakan-1.185546

Kaung, M. (2012). Merdeka “ no relevance" to Sabah , Sarawak. Free Malaysia Today. Retrieved from http://www.freemalaysiatoday.com/category/nation/2012/08/27/merdeka-no-relevance-to-sabah-sarawak/

Körber, A. (2015). Historical consciousness, historical competencies - and beyond ? Some conceptual development within German history didactics, 1-56.

Luisa, B. M. (2011). History teaching today: approaches and method. Retrieved from http://www.theewc.org/uploads/content/archive/History_teaching_today_manual_1.pdf

Radin. (2012). 22 Julai; Hari Kemerdekaan Sarawak. Retrieved October 5, 2016, from http://radin87discussion.blogspot.my/2012/07/22-julai-hari-kemerdekaan-sarawak.html

Razak, D. S. M. N. B. T. H. A. (2011). Perutusan Hari Malaysia. Kuala Lumpur Retrieved from http://www.pmo.gov.my/home.php?menu=speech\&page=1908\&news_id=525\&speech_cat=2 .

Sarawak, G. of. (2016). Self - Governing Sarawak 1963. Retrieved September 29, 2016, from http://www.sarawak.gov.my/web/home/article_view/238/249/

Stockwell, A. J. (2008). The Journal of Imperial and Malaysia : The making of a neo - colony ?, (October 2014), $37-$ 41. http://doi.org/10.1080/03086539808583029

Ting, H. (2014). The battle over the memory of the nation: Whose national history? In L. K. S. Mark Baildon, G. İ. and Ivy Maria Lim, \& J. Jaffar (Eds.), Controversial History Education in Asian Contexts (pp. 41-57). Oxon: Routledge. Retrieved from http://samples.sainsburysebooks.co.uk/9781135014216_sample_717252.pdf

Welman, F. (2011). Borneo Trilogy Sarawak: Volume 2. Booksmango.

William, L. (2015). Sarawak Was Granted Self-Government on 22 July, 1963. Retrieved from http://www.sabahsarawakmerdeka.com/2015/07/sarawak-was-granted-self-government-on.html

$\mathrm{Yu}$ Ji. (2016). Adenan: July 22 is now Sarawak Day. The Star Online. Retrieved from http://www.thestar.com.my/news/nation/2016/04/23/adenan-sarawak-day/ 